GU J Sci, Part C, 6(3): 558-569 (2018)

Gazi Üniversitesi
Fen Bilimleri Dergisi
PART C: TASARIM VE TEKNOLOJI
dergipark.gov.tr/http-gujsc-gazi-edu-tr

\title{
Stronsiyum Katkılı Biyocam ve Bakır Nanoparçacıklarından 3D Kompozit Yapı İskelesi Üretimi
}

\author{
Ayşe ÖZYUĞURAN ${ }^{1, *}$ \\ ${ }^{1}$ Istanbul Teknik Üniversitesi, Kimya-Metalurji Fakültesi, Kimya Mühendisliği Bölümü, 34469, Maslak/ISTANBUL
}

\begin{abstract}
$\ddot{\text { Öz }}$
Makale Bilgisi

Basvuru: $30 / 01 / 2018$

Düzeltme: $30 / 04 / 2018$

Kabul: 29/05/2018

\section{Anahtar Kelimeler}

Kompozit Yapi Iskelesi

Bu çalışmada, çözücü döküm ve tanecik uzaklaştırma yöntemi kullanılarak, çok işlevli yap1 iskelelerinin geliştirilmesi için ilgili iyonlarla biyoaktif cam (BG) / polimer 3D kompozit yapı iskelelerinin üretilmesi amaçlanmıştır. Gözenekli yapıya sahip yapı iskeleleri başarıyla sentezlenmiş ve yapı iskelelerinin mikroyapısında iyi bir gözenek bağlantısının bulunduğu gözlemlenmiştir. Kompozit yapı iskelelerinin in vitro biyoaktivitesi; Taramalı Elektron Mikroskopisi (SEM), X-ışını kırınımı (XRD) ve Fourier-Dönüşümlü Kızılötesi Spektroskopi (FTIR) ölçümleri ile teyit edilmiştir. Bunun dışında, terapötik iyonların salınımının; SBF (Simulated Body Fluid)'de kalma sürelerinin bir fonksiyonu olarak, stronsiyum ve bakır iyonları için sırasıyla 1.27-5.36 ppm ve 1.53-5.42 ppm aralığında değiştiği belirlenmiştir. Bu sonuç yapı iskelelerinin, kemik dokusu rejenerasyonunun belirleyicisi olan SBF ortamina, stronsiyum ve bakır dozlarının kontrollü olarak verebileceğini göstermiştir.
\end{abstract} Biyoaktif Cam

Terapötik İonlar

Kemik Doku Mühendisliği

Keywords

Composite Scaffolds

Biactive Glass

Therapeutic Ions

Bone Tissue Engineering

\section{D Composite Scaffold Production Using Sr-Doped Bioglass and Copper Nanoparticles}

\begin{abstract}
In this study, it was aimed to produce BG/polymer 3D composite scaffolds with relevant ions in order to develop multifunctional scaffolds by using salt template-partibakırlate leaching technique. The porous scaffolds were successfully synthesized and it was observed that there was a good pore interconnectivity maintained in the scaffold microstructure. In vitro bioactivity of the composite scaffolds was confirmed by Scanning Electron Microscopy, X-ray diffraction and Fourier-Transform Infrared Spectroscopy measurements. Furthermore, the release of therapeutic ions were determined as a function of immersion time in SBF, which was in the range of 1.27$5.36 \mathrm{ppm}$ and 1.53-5.42 ppm for strontium and copper ions, respectively. This result indicated that the scaffolds can deliver controlled doses of strontium and copper toward the SBF medium that is the determinant for bone tissue regeneration.
\end{abstract}

\section{GİRIŞ (INTRODUCTION)}

Yaşlanan nüfusun artmasıyla, dejeneratif hastalıklar ya da travmatik yaralanmalar insan yaşamının kalitesinde önemli rol oynayan kemik kusurlarına yol açmaktadır. Çözümlerden biri kemik naklidir, fakat uygun donörün bulunamaması en önemli problemlerden biridir. Biyoinert malzemelerin kullanımı ile gerçekleştirilen implantasyon işlemi, kemik yoğunluğunda azalmaya neden olmaktadır. Ayrıca, kullanılan bu malzemelerin belli sürelerle değiştirilmesi gerekmektedir [1]. Kemik dokusu mühendisliği, yaralı kemik dokularını biyolojik olarak bozunabilir yapı iskelesi yardımıyla onarmak, değiștirmek ya da yenilemek amacıyla hızla gelişen bir disiplindir. Bu yaklaşımın avantajı, hastanın iyileşmesi için yapılması gerekli operasyon sayısının azalması, dolayısıyla da hastanın iyileşme süresinin kısalmasıdır [1-3].

Geleneksel metotlara alternatif bir yaklaşım olan doku mühendisliği; kalıcı protez kullanılmaksızın hasar görmüş, hastalıklı veya kayıp dokuların yenilenmesi, onarılması ve yenisiyle değiştirilmesi için 
mühendislik, biyoloji ve tıp ilkelerini ve yöntemlerini bir araya getirmektedir [1, 4]. Bu bağlamda, ilgili hücrelerin çoğalması için geçici bir matris görevi gören bir şablon (yapı iskelesi) kullanılır. Yapı iskelesi kullanımı; yapısal, morfolojik ve biyolojik olarak doku yapısını taklit etmenin yanı sıra, donör kıtlığı, bağışıklık problemleri ve patojen transferi gibi sorunları da ortadan kaldırmaktadır $[1,2,5,6]$.

Mükemmel bir yapı iskelesi üretmek, doku mühendisliğinin en zor aşamasıdır. Genel olarak, tek bir malzemenin özelliklerinin yetersiz olduğu durumlarda, iki veya daha fazla malzemenin özelliklerini birleştirerek, yeterli mekanik ve / veya kimyasal özelliklere sahip malzemeleri elde etmek için kullanılan yaygın bir tekniktir [7]. Doğal kemik matrisi, biyolojik seramik ve biyolojik polimerin bir bileşimidir. Bu nedenle, kemik dokusu mühendisliği uygulamalarında kullanılmak üzere, biyoaktif camlar ve biyo-emilir polimerlerin kombinasyonu ile istenen fiziksel, biyolojik ve mekanik özelliklere sahip bir yapı iskelesi üretmek oldukça mantıklıdır [7-9]. İnorganik biyoaktif maddelerin bir alt kümesi olan biyoaktif cam (BG), ilk defa Hench ve Ç.A. tarafından üretilmiştir [10]. Biyoaktif camlar insan vücuduna implante edildiğinde veya biyolojik sıvılarla temas ettiğinde, içeriklerinde bulunan $\mathrm{Si}, \mathrm{Ca}, \mathrm{P}$ ve $\mathrm{Na}$ iyonları ara yüzeylerde çözünürler ve hücre içi ile hücre dışında uygun tepkilere girerek hızlı kemik oluşumuna neden olurlar [11]. Böylece biyoaktif cam yüzeyinde bir karbonatlı hidroksiapatit (HA) tabakası oluşturulur. Bu HA tabakası, biyoaktif camın gerçek kemik yapısına kimyasal olarak bağlanmasını sağlar [7, 9, 12].

Son y1llarda, biyo-polimerlerin ve biyoaktif camların kombine edilmesi ile geçici ortopedik implantlar, kemik dolgu malzemeleri veya doku mühendisliği alanında üç boyutlu (3D) biyouyumlu yapı iskeleleri gibi uygulamalar için yeni bir kompozit malzeme grubu ortaya çıkmıştır [12-15]. Bu kompozit malzemelerin kemik üretim özelliklerini iyileştirmek için, kemik hücre uyarıcı iyonları (stronsiyum, bakır, gümüş, v.b) kompozit malzemenin kimyasal bileşimine dahil etmek çok uygulanan bir yöntemdir. Stronsiyumun kemik iyileştirme süreçlerini hızlandırdığı ve kemik dokusu onarımı üzerinde olumlu etkilerinin olduğu bilinmektedir [16]. In vitro ve in vivo çalışmalar, stronsiyumun kemik oluşumunu artırdığını ve osteoporozu azalttığını ve hayvanlarda ve insanlarda kemiğin kütlesinde ve kemiğin mekanik özelliklerinde bir artışa neden olduğunu göstermiştir [17]. Bakır iyonları, anjiyojenezin uyarılmasında aktif bir rol oynamaktadır [18]. Erol ve Ç.A. [19], bor içeren biyoaktif cam kullanarak yeni yapı iskeleleri oluşturmuşlar ve bakır iyonlarıyla çapraz bağlanmış alginat ile kaplamışlardır. Bakır salınım çalışmaları, yeni yapı iskelelerinden bakır iyonlarının kontrollü bir şekilde serbest bırakıldığını ve dolayısıyla bu etkinin, kemik rejenerasyonu için anjiyojenik potansiyel olarak yararlı olabileceğini göstermiştir [19].

Bu çalışmada, büyük kemik defektlerini onarmak için çoklu kullanıma uygun, biyoaktif cam kaynaklı, çok fonksiyonlu 3D kompozit yapı iskelelerinin elde edilmesi araştırılmıştır. Bu amaçla, 3D biyoaktif campolilaktid (PDLLA) kompozit gözenekli yapı iskeleleri, bakır nanoparçacıklarının varlığında çözücü döküm ve tanecik uzaklaştırma yöntemi kullanılarak üretilmiştir [20]. Üretilen yapı iskelelerinin mikroyapısal, fiziksel ve biyoaktivite özellikleri farklı karakterizasyon yöntemleri uygulanarak belirlenmiştir.

\section{DENEYSEL ÇALIŞMA (EXPERIMENTAL STUDY)}

\section{a. Malzemeler}

Yap1 iskelesi üretiminde kullanılan rasemik poli (D, L-laktit) (PDLLA) granülleri (75,000-120,000 mol ağırlığı) Sigma-Aldrich Ltd. (ABD) 'den satın alınmıştır. Çözücü olarak, susuz dimetil karbonat (DMC, Merck) kullanılmıştır. Bu çalışmada yapı iskelelerinin imalinde kullanılan stronsiyum içeren biyoaktif cam tozu önceki çalışmamızda üretilmiştir [21]. Bu camın ağırlıkça yüzde bileşimi, \%45 $\mathrm{SiO}_{2}, \% 24.5 \mathrm{Na}_{2} \mathrm{O}, \% 6$ $\mathrm{P}_{2} \mathrm{O}_{5}, \% 22.5 \mathrm{CaO}$ ve \%2 Sr'dan oluşmaktadır. Biyoaktif cam (BG), seramik bilyalı değirmende tanecik boyutu $\leq 45 \mu \mathrm{m}$ olacak şekilde öğütülmüştür. Kullanılan diğer tüm kimyasalların analitik saflıkta olmasına dikkat edilmiştir. 


\section{b. Bakır nanoparçacıklarının üretimi}

Bakır nanoparçacıkları, $\mathrm{CuSO}_{4}$ 'tan üretilmiştir. Deiyonize su ile seyreltilmiş $\mathrm{CuSO}_{4}$ çözeltisinin pH'ı, yavaş yavaş amonyak eklenerek 10'a ayarlanmıştır. $100 \mathrm{~mL}$ aljinat çözeltisi üzerine, hazırlanan $\mathrm{CuSO}_{4}$ çözeltisi yavaşça karıştırılarak ilave edilmiştir. Çözeltiler birbirine tamamen karıştıktan sonra, bakır iyonlarını indirgemek için, hidrazin ilave edilmiştir. Elde edilen çözelti, mikrodalga firında (600 watt) 2 dakika 1sıtılmıştır. Bu işlemin ardından bakır partiküllerini elde etmek için santrifüj tekniği kullanılmış, çözelti üç kez 22000 rpm'de 40 dakika süreyle santrifüjlenmiştir. Santrifüjlemeden sonra bakır parçacıkları distile su ile yıkanmış, bakır nanoparçacıklarının tamamen kurumasını sağlamak için vakum etüvünde gece boyunca bekletilmiştir.

\section{c. Yapı iskelelerinin üretimi}

Yap1 iskeleleri, $\mathrm{NaCl}$ kullanılarak çözücü döküm ve tanecik uzaklaştırma yöntemi [20] uygulanılarak hazırlanmıştır. PDLLA pelletleri, çözelti konsantrasyonları \%8 w/v ve $\% 4 \mathrm{w} / \mathrm{v}$ olacak şekilde DMC'de çözülmüştür. Bakır nanoparçacıkları, polimer ağırlığının \%1'i olacak şekilde çözeltilere ilave edilmiştir. Bakır nanoparçacıkların ilavesinden sonra, parçacıkların tamamen dağılmasını sağlamak için, süspansiyonlar iyice karıştırılmıştır. Daha sonra, süspansiyonların bileşimlerinde \%20 stronsiyum olacak şekilde uygun miktarda $\mathrm{BG}$ eklenmiştir. Parçacıkların dağılımının tamamlanması ve topaklanmanın önlenmesi için süspansiyonlar ultrasonik su banyosu kullanılarak karıştırılmıştır. Böylece, PDLLA-BG-Cu süspansiyonları elde edilmiştir. $\mathrm{NaCl}$ taneleri tanecik boyutu 501-850 $\mu \mathrm{m}$ aralığında olacak şekilde ögütülmüştür. Yapı iskelesi üretimi için, tuz taneleri (1.5 g), $1 \mathrm{~mL}$ PDLLA-BG-Cu süspansiyonuyla (8 w/v) tamamen karıştırılarak viskoz macun kıvamına getirilmiştir. Daha sonra bu karışım silikon tüplere (iç çap: $9 \mathrm{~mm}$ ) doldurulmuş ve bir cam pim yardımıyla elle sıkıştırılmıştır. Bu şekilde elde edilen yapı iskelesi kalıpları (çap $\approx 9 \mathrm{~mm}$, yükseklik $\approx 20 \mathrm{~mm}$ ) bir inkübatör $\left(37^{\circ} \mathrm{C}\right.$ ) içinde gece boyunca kurutulmuştur. Kalıplar, 2 gün süreyle 4 w/v PDLLA-BG-Cu süspansiyonu ile tekrar infiltre edilmiştir. Kurutulan kalıplar, 4-6 mm kalınlığında küçük silindirler halinde kesilmiş ve tuzun tam olarak çözülmesine izin vermek için $37^{\circ}$ C'de 2.5-3 saat boyunca 0.5 L deiyonize su içinde bırakılmıştır. Sudan çıkarılan örnekler, yapı iskelelerinde kalan suyun tamamını kurutmak için bir inkübatör içine yerleştirilmiştir.

\section{d. Yapı iskelelerinin mikroyapısal karakterizasyon}

Gözenekli yapı iskelelerinin SBF içine batırılmadan önceki ve sonraki yüzey morfolojisi ve mikroyapılarını gözlemlemek için, 10 kV'de çalıştırılan bir taramalı elektron mikroskopu (SEM) (Quanta 250 FEG) kullanılmıştır. SEM ölçümlerinden önce, tüm numuneler vakum altında platin ile kaplanmıştır.

3D yapı iskelelerinin X-1şını kırınımı (XRD) analizleri, numunelerin karakteristik fazlarını ve olası kristalliğini araştırmak için, PANanalytical X'Pert Pro difraktometresi kullanılmıştır. Veriler, 10-60 aralığındaki $2 \theta$ açılarında $\mathrm{CuK} \alpha$ radyasyonu ( $35 \mathrm{kV}$ ve $40 \mathrm{~mA}$ 'de) kullanılarak elde edilmiştir.

Fourier-dönüşümlü kızılötesi spektroskopi (FT-IR) spektrumu, 650-4000 bölgesindeki $\left(\mathrm{cm}^{-1}\right)$ geçirgenlik modunda çalışan bir Perkin Elmer Spectrum 100 Model spektrometresi kullanılarak toplanmıştır.

Yapı iskelelerinin biyoaktif davranış testi, Kokubo ve Ç.A. tarafından tarif edildiği gibi, numunelerin SBF içinde bekletilmesiyle gerçekleştirilmiştir [22]. Yapı iskelesi örnekleri $200 \mathrm{~mL}$ SBF içine batırılmış ve $37^{\circ}$ C sıcaklıkta tutulan bir inkübatörde tutulmuşlardır. Örnekler SBF'den 1, 7, 14 ve 28 gün sonra çıkarılmış ve $37^{\circ} \mathrm{C}$ 'deki inkübatörde $4 \mathrm{~s}$ boyunca kurutulmuştur. Numuneler daha sonra SEM, XRD ve FTIR kullanılarak karakterize edilmişlerdir. Yapı iskelelerinin 1, 7, 14 ve 28 gün boyunca SBF (Simulated Body Fluid) içinde bekletilmesinin bir sonucu olarak, SBF çözeltisinde stronsiyum ve bakır iyon konsantrasyonunda meydana gelen değişim, indüktif çift plazma optik emisyon spektrometresi (ICP-OES) kullanılarak ölçülmüştür. Ölçümler için, $13.56 \mathrm{MHz} d e$ çalıştırılan (Ar ve $\mathrm{N}_{2}$ gazı kullanan) bir Perkin Elmer Model Optima 2100 ICP kullanılmıştır. 


\section{SONUÇLAR VE TARTIŞMA (RESULTS AND DISCUSSION)}

\section{a. Mikroyapısal karakterizasyon}

Üretilen bakır nanoparçacıklarının karakterizasyonu XRD ve SEM analizleri kullanılarak yapılmıştır. Şekil 1 'de standart JCPDS kartlarına göre üretilen yapı iskelelerinin içeriğindeki bakır nanoparçacıklarına ait pik listesini göstermektedir. (20-04-2018) kodlu JCPDS kartına göre $44.10^{\circ}, 51.20^{\circ}, 75.5^{\circ}, 91.2^{\circ}$ ve $96.5^{\circ}$ $2 \theta$ 'da görülen pikler bakır nanoparçacıklarını temsil etmektedir.

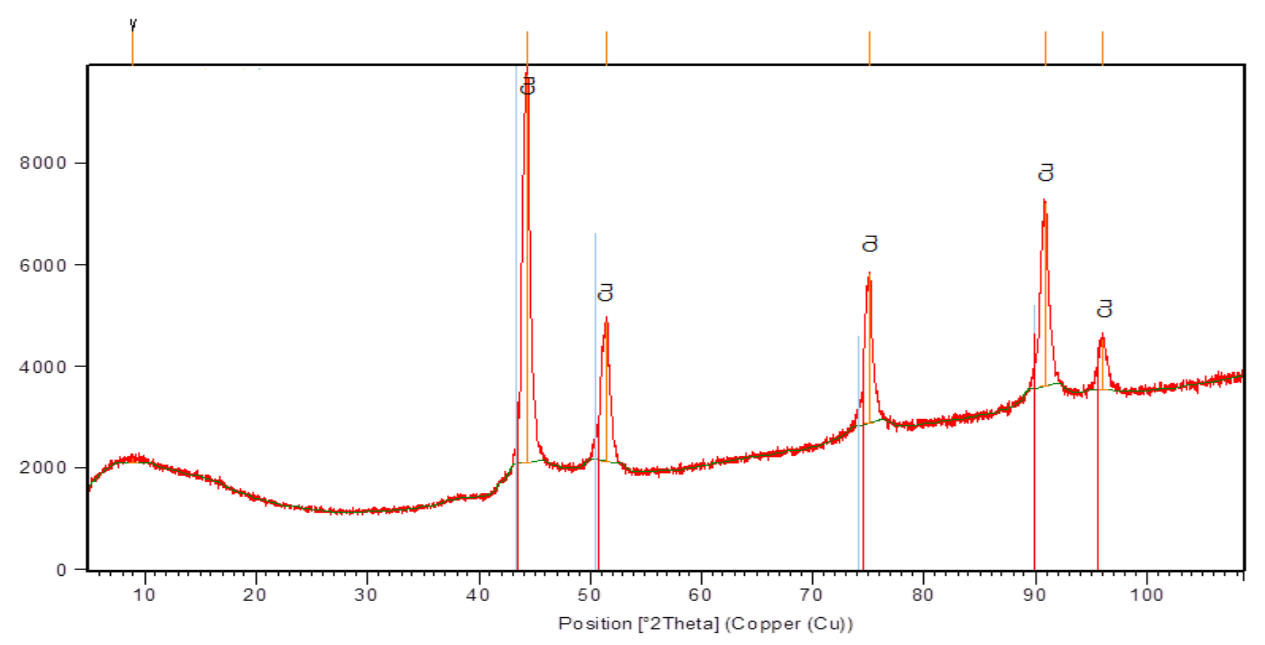

Şekil 1. Bakır nanoparçacıklarının XRD analizi

Şekil 2'de bakır nanoparçacıklarının SEM analizi verilmektedir. Yapılan ölçümler sonucunda, santrifüj yöntemi ile üretilen bakır nanoparçacıklarının tanecik boyutunun 39.7-85.0 nm arasında değiştiği saptanmıştır. 55 tanecik üzerinden yapılan ölçümler sonucunda da, ortalama tanecik boyutunun $60.0 \pm 10.6$ nm olduğu belirlenmiştir.

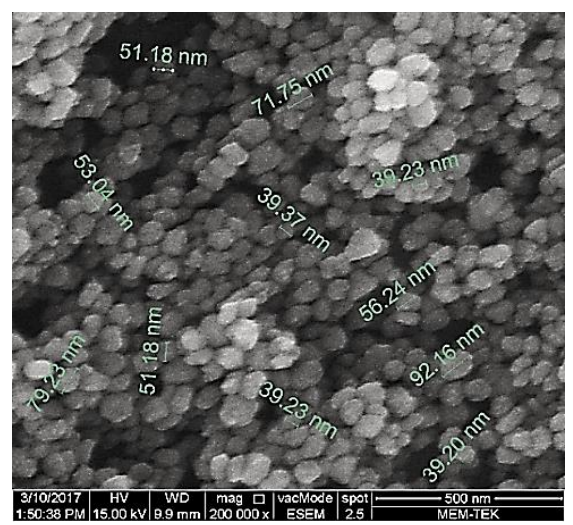

Şekil 2. Bakır nanoparçacıklarının SEM görüntüleri

Üretilen yapı iskelelerinin makrogözenekli ağ yapısı Şekil 3'te gösterilmiştir. Şekil 3a ve 3b'den görülebileceği gibi birbirine bağlı gözenek yapısına sahip, oldukça gözenekli yapı iskeleleri üretilmiştir. Kompozit yapı iskelesi yüzeyinde polimer yapısının dışında görülen parlak beyaz parçacıklar, $\mathrm{NaCl}$ kristalinden farklı bir morfolojiye sahip oldukları için bunların biyoaktif cam parçacıkları oldukları düşünülmektedir (Şekil 3c-3d). Bu sonuç, takip eden bölümdeki FTIR sonuçlarıyla da desteklenmektedir.

Kemik doku mühendisliğinde, hücrelerin büyümesi, bağlanması ve çoğalması, besinlerin ve metabolik atıkların taşınması için gözenekli bir yapıya ihtiyaç vardır. Ayrıca, hücrelerin istenen fiziksel forma dönüşmesini ve büyümüş dokunun vaskülarizasyonunu desteklemesi için de kontrol edilebilir ve birbirine bağlı bir gözenekliliğin olması zorunludur $[8,12,23]$. SEM sonuçlarından, üretilen yapı iskelelerinin 
birbirine bağlı gözenekli bir yapıya sahip olmasının, yap1 iskelelerinin hücre bağlanması, göçü ve vaskülarizasyonu için uygun olduğu sonuca varılmıştır.
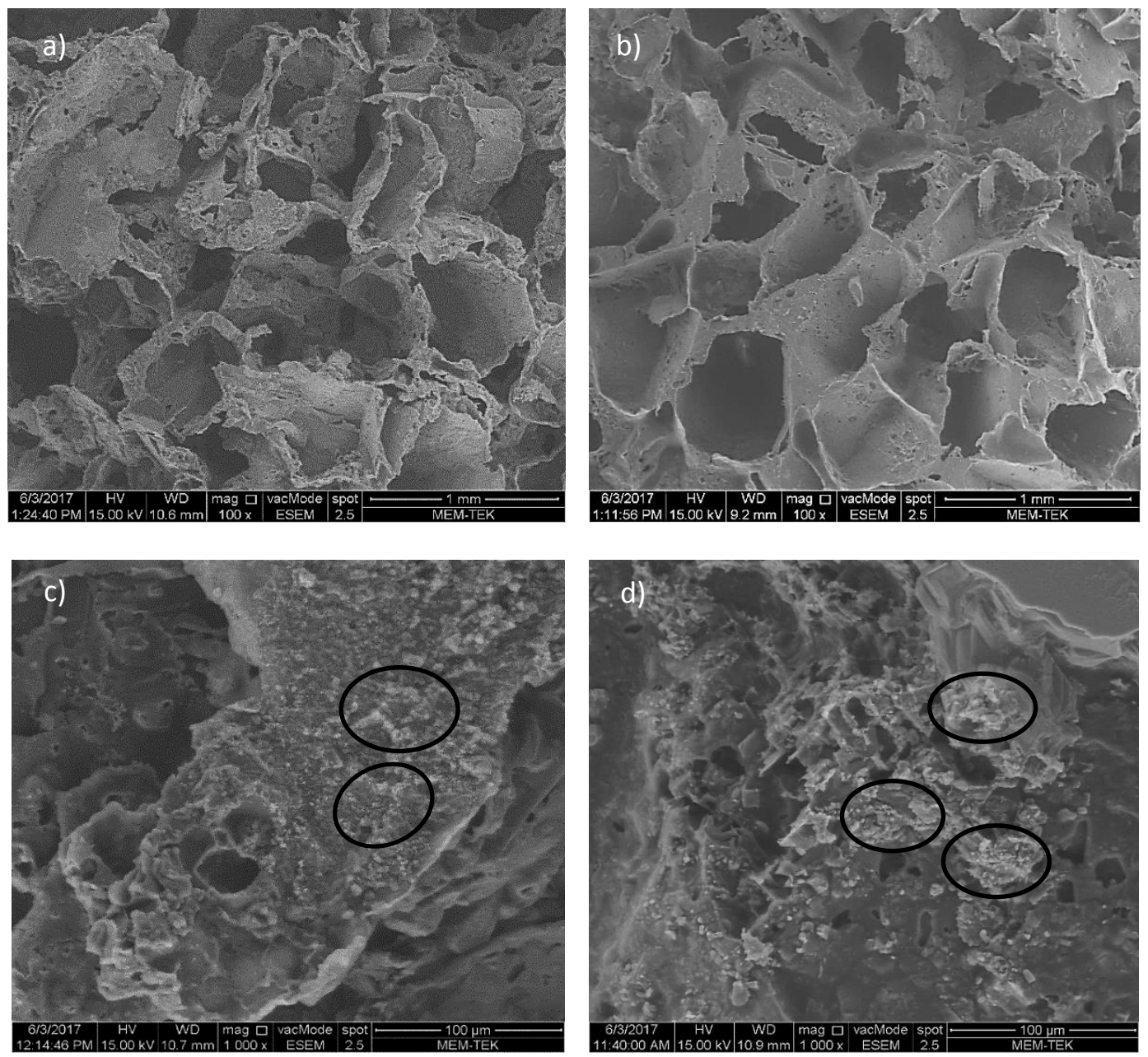

Şekil 3. Üretilen kompozit yapt iskelelerinin SEM görüntüleri

FTIR, XRD ve SEM analizleri, SBF ile temas halinde olan tüm yapı iskelesi yüzeyinde oluşan HA tabakasını saptamak için gerçekleştirilmiştir. SBF'de bekletme öncesi ve sonrasında, ağırlıkça \%1 bakır nanoparçacıkları içeren yap1 iskeleleri için FTIR spektrumu Şekil 4'te verilmiştir. SBF öncesi yap1 iskelelerinin $3000 \mathrm{~cm}^{-1}$ ve $2945 \mathrm{~cm}^{-1}$ de bulunan pikleri, PDLLA'nın metil ve metilen gruplarının gerilmesinden kaynaklanmaktadır [24, 25]. PDLLA'nın karakteristik bantlarından biri olan ester karbonil gruplarının gerilme modu $(\mathrm{C}=\mathrm{O}) 1747 \mathrm{~cm}^{-1}$ de gözükmektedir $[24,26] .1452 \mathrm{~cm}^{-1}$ ve $1381 \mathrm{~cm}^{-1}$ deki pikler sirasıyla $\mathrm{CH}_{3}$ asimetrik ve $\delta \mathrm{s} \mathrm{CH}_{3}$ simetrik deformasyon modlarını göstermektedir [24-26]. $1263 \mathrm{~cm}^{-1}$ ' de görünen pik, ester gruplarının -CO-O- gerilme bantlarına aittir [25, 27]. Bu piklere ek olarak, 1183, 1135, 1082 ve $1043 \mathrm{~cm}^{-1}$ deki pikler ise $=\mathrm{C}-\mathrm{O}$ gerilme bantları olduğu belirlenmiştir. $\sim 864 \mathrm{~cm}^{-1}$ ve $\sim 750 \mathrm{~cm}^{-}$ ${ }^{1}$ 'deki iki pik, PDLLA'nın CH eğilme titreşim bantlarını göstermektedir [26]. Si-O-Si asimetrik gerilme titreşimine karşıllı gelen bant, $1080 \mathrm{~cm}^{-1}$ de [28] saptanmıştır. $950 \mathrm{~cm}^{-1}$ civarındaki pik, non-bridging oksijen içeren Si-O-Ca bağlarını göstermektedir [28, 29]. SBF öncesi yapı iskelesi numunesinin FTIR spektrumu, kullanılan biyocam ağ yapısının tüm özelliklerinin üretilen yapı iskelesinde görüldüğünü kanıtlamaktadır. Bu sonuçlardan, biyoaktif camın PDLLA matrisinin içine başarılı bir şekilde adapte edildiği açıkça görülmektedir. 


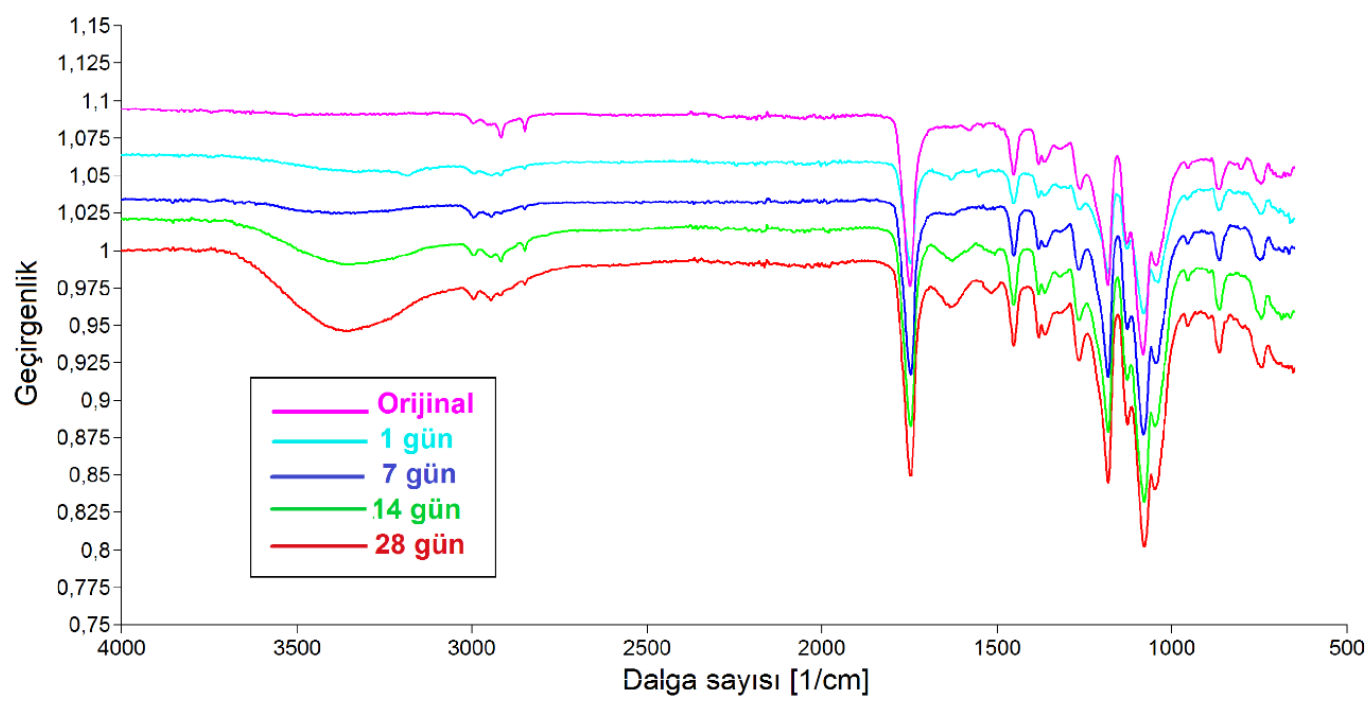

Şekil 4. \%1 Bakır nanoparçacıkları içeren yapı iskelelerinin FTIR spektrumu

SBF'de bekletme sonrasındaki yapı iskelelerinin FTIR spektrumunda, HA'nin kristal yapısında bulunan, yapısal OH- grubunun gerilmesini karakterize eden geniş band 3000 ila $3600 \mathrm{~cm}^{-1}$ aralığında görülmektedir [30, 31]. SBF sonrasındaki yap1 iskelelerinin FTIR spektrumunda yeni absorpsiyon bantlar1 da gözlemlenmiştir. $3186 \mathrm{~cm}^{-1}$ ve $2917 \mathrm{~cm}^{-1}$ deki pikler, sırasıyla $\mathrm{CO}_{3}$ grupları [32] ve HA'nın C-H bantlarını karakterize [33] etmektedir. $1630 \mathrm{~cm}^{-1}$ ve $1550 \mathrm{~cm}^{-1}$ deki pikler ise, su absorpsiyon bandina ve $\mathrm{CO}_{3}$ (v3) titreşim piklerine aittir [34]. Yapı iskelelerine ait FTIR spektrumları incelendiğinde, SBF öncesi ve sonrası spektrumlarında bir takım farklılıklar gözlenmiştir. $1043 \mathrm{~cm}^{-1}$ deki pikin $1035 \mathrm{~cm}^{-1} \mathrm{e}$ kaydığı ve bu pikin SBF öncesindeki yapı iskelesinin spektrumu ile kıyaslandığında daha büyük ve daha keskin bir bant haline geldiği saptanmıştır. Pikteki bu değişimin nedeninin, oluşan $\mathrm{PO}^{-3}$ gruplarının simetrik gerilme ve eğilme moduyla ilişkili olabileceği düşünülmüştür [30, 31, 34]. SBF'de bekletme sonrası tüm numunelerin FTIR spektrum sonuçları, yapı iskelesinin her tarafında HA oluşumunun gerçekleştiğini göstermektedir.

SBF'de bekletme öncesi ve sonrasında, ağırlıkça \%1 bakır nanoparçacıkları içeren yapı iskeleleri için XRD analizleri Şekil 5'te verilmiştir. Şekil 6 ise, standart JCPDS kartlarına göre üretilen yapı iskelelerinin içeriğindeki $\mathrm{NaCl}$ ve $\mathrm{HA}$ tabakası kristal yapısının pik listesini göstermektedir. (01-083-1728) kodlu JCPDS kartına göre $32.8^{\circ}, 47.1^{\circ}$ ve $58.5^{\circ} 2 \theta^{\prime}$ da görülen pikler NaCl' $\ddot{\text { u, }},(01-084-1998)$ kodlu JCPDS kartına göre $33^{\circ}$ ve $48^{\circ} 2 \theta^{\prime}$ da görülen pikler HA'i temsil etmektedir. NaCl'e ait çıkan pikler, yapı iskelesi içinde halen çözünmemiş halde $\mathrm{NaCI}$ kristallerinin kaldığını göstermektedir.

Şekil 5 incelendiğinde, yapı iskelesi orijinal örnekle kıyaslandığında SBF içinde bekletilme süresi uzadıkça $33^{\circ} 2 \theta^{\prime}$ da görülen pikin önce şiddetinin ( 1 ve 7 gün numuneleri), daha sonra da (14 ve 28 gün numuneleri) bant genişliğinin arttı̆̆ saptanmıştır. Bu da kompozit yapı iskelesi yüzeyinde oluşan HA tabakasının kademeli olarak arttığını göstermektedir. Erol ve Ç.A. yaptıkları çalışmalarda benzer sonuçlar elde ettiklerini belirtmişlerdir $[19,21]$. Bor katkılı biyoaktif cam kullanarak sünger kopyalama yöntemi ile ürettikleri yapı iskelelerini aljinat ile kaplamışlar ve bu yapı iskelelerinin SBF'de 7 gün bekletildikten sonra HA tabakasının oluşmaya başladığını belirtmişlerdir [19]. Diğer çalışmalarında ise, stronsiyum katkılı biyoaktif cam kullanarak aynı yöntemle ürettikleri yapı iskelelerini bu kez jelatin ile kaplamışlar ve SBF'de bekletilmesinden 1 gün sonra HA tabakasının oluşmaya başladığını saptamışlardır [21]. Bu çalışmada da, farklı bir üretim yöntemi kullanılarak üretilen yapı iskelelerinin SBF'de bekletilmesinden 1 gün sonra HA tabakasının oluşmaya başladığı açıkça görülmektedir.

Ayrıca XRD analizi, yapı iskelesi yüzeyindeki HA oluşumunun FTIR sonuçlarını doğruladığını ortaya koymuştur. 


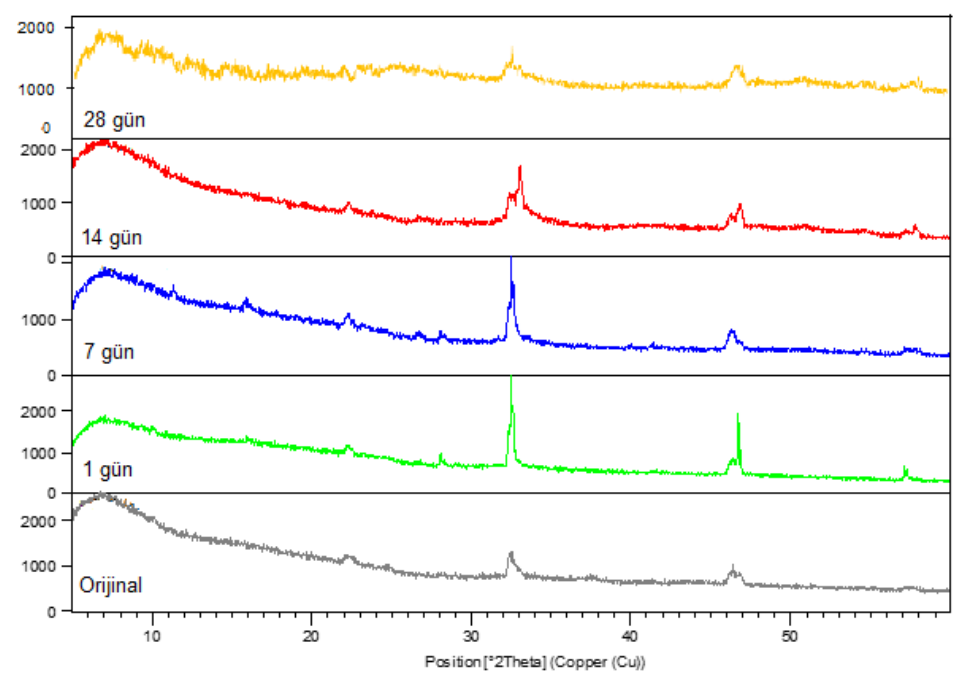

Şekil 5. Üretilen yapı iskelelerinin SBF öncesi ve sonrası XRD analizi sonuçları

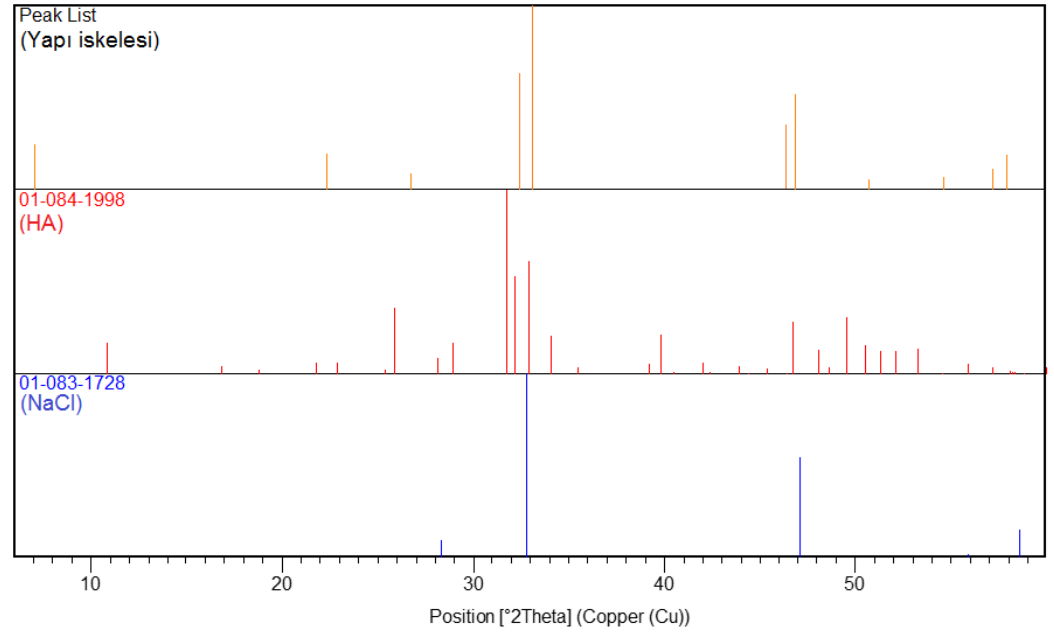

Şekil 6. Standart JCPDS kartlarına göre yapt iskelesinde saptanan HA tabakasının ve NaCl kristalinin pik listesi

SEM, biyoaktif yapı iskelesi yüzeyinde oluşan bir HA tabakasının oluşum süreci hakkında ayrıntılı bilgi vermektedir. SBF çözeltisinde bekletilmiş yapı iskelelerinin mikroyapısal gelişimini incelemek için, SBF sonras1 örnekler üzerinde SEM incelemesi yapılmıştır. SBF'ye daldırıldıktan 1, 7, 14 ve 28 gün sonra, bakır nanoparçacıkları içeren yapı iskelelerinin SEM görüntüleri Şekil 7'de verilmiştir. Şekil 7'den görüleceği üzere, yapı iskelesi yüzeyi yeni oluşturulmuş bir HA tabakası ile kaplanmıştır. SBF'de 28 gün bekletilen numunelerin yüzeyinde, HA tabakasının daha yoğun olarak oluştuğu Şekil $7 \mathrm{~g}$ ve $7 \mathrm{~h}$ 'de açikça görülmektedir. 

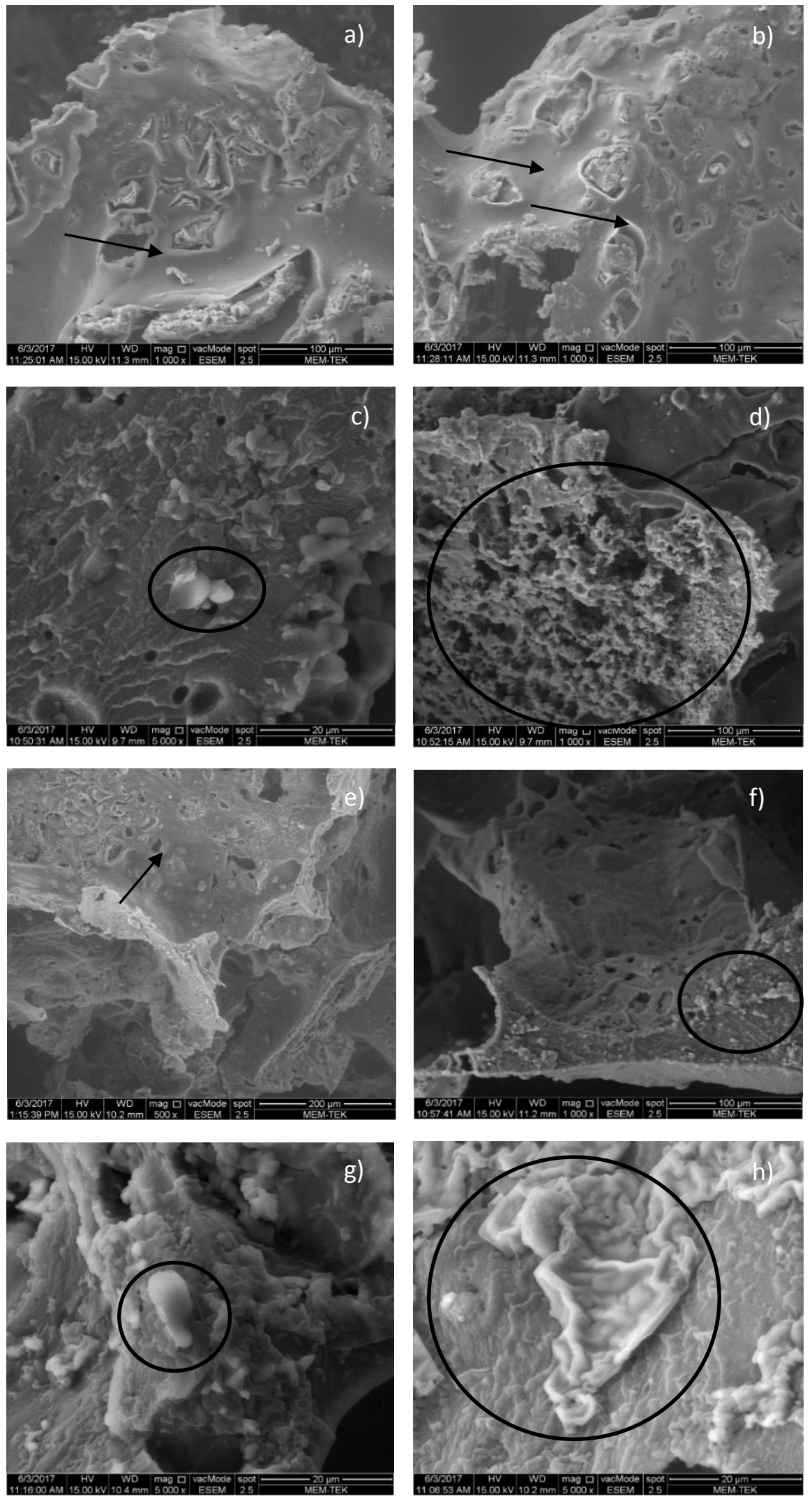

Şekil 7. Bakır nanoparçacıkları ve Sr katkılı BG içeren yapı iskelelerinin SBF sonrası SEM görüntüleri a/b) 1 gün, c/d) 7 gün, e/f) 14 gün, g/h) 28 gün 
Yap1 iskelesi yüzeylerinde bazı küçük parçacıklar oluşmuştur. Bu HA kristallerinin, BG parçacıklarının SBF ile temasının bir sonucu olarak oluştuğu öngörülmektedir. Hench tarafından önerilen ve genel olarak bilinen HA oluşum mekanizmasının, yapı iskelesi yüzeyi ile SBF çözeltisi arasındaki iyonik değişime dayandığı bilinmektedir [10]. Şekil 7'den görülebileceği gibi, polimer tabakası üzerinde oluşturulan polimer matrisinin kaybolmasına kanıt olabilecek küçük gözenekler oluşmuştur. Bu, polimerin biyobozunma sürecinin (degradation) başladığını göstermektedir [21]. Aynı zamanda bu gözeneklerin oluşması, polimer matrisine gömülü olan BG parçacıklarının SBF ile temas etme şansı bularak, yapı iskelesi yüzeyinde HA tabakasının oluşumuna neden olduğu anlamına gelmektedir [10, 21, 35].

Sonuç olarak, XRD analiz sonuçları, FTIR ve SEM sonuçları SBF'de bekletme süresi arttıkça oluşan HA tabakasının yoğunlaştığını, bütün sonuçların birbirini desteklediğini göstermektedir.

\section{b. Bakır ve stronsiyum salımı}

İyon değişimi sürecini cam çözünme hızı ile ilişkilendirmek için, yapı iskelelerinin bakır ve stronsiyum salım davranışları belirlenmiştir. Şekil 8, yapı iskelesi örneklerinin SBF çözeltisinde bekletilmeleri sonrasında çözeltiye geçen bakır ve stronsiyum iyonlarının konsantrasyonlarını göstermektedir. Şekil 8'den görülebileceği gibi, bakır ve stronsiyum iyon miktarları SBF içinde bekletilme süresinin uzamasıyla artmıştır. Bu sonuç, camın yapısında bulunan stronsiyum iyonu ile yapı iskelesi yapımında kullanılan bakır nanoparçacıklarının iyon değişim prosesi temeline dayalı gerçekleşen camın çözünmesi ile ilişkilendirilebilir. Üretilen yapı iskelesinden olan bakır ve stronsiyum iyon salım konsantrasyonlarının hemen hemen aynı olduğu da açıkça görülmektedir (Şekil 8).

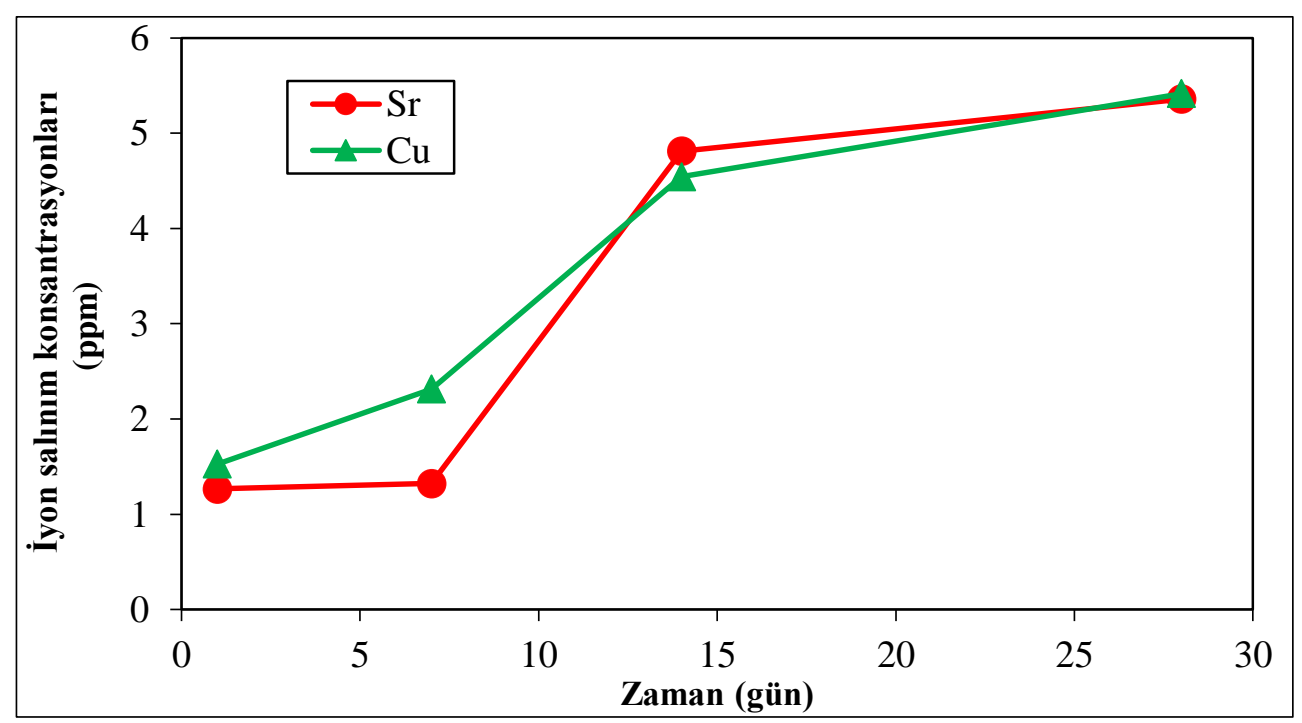

Şekil 8. Yapı iskelesinden bakır ve stronsiyum iyon salım konsantrasyonlarının zamanla değiş̧imi

Bakır iyonları, insan hücrelerine iyon konsantrasyonuna bağlı olarak farklı etkiler göstermektedir. Örneğin; 1 ppm ila 100 ppm arasında bir bakır konsantrasyonu söz konusu olduğunda, endotel hücrelerinin (EC'ler) oluşturduğu minik kart ve tüp benzeri yapıların oluşması için optimal $\mathrm{CuSO}_{4}$ konsantrasyonunun $50 \mathrm{ppm}$ olduğu belirlenmiştir [36]. \%10 $\mathrm{CuO}$ içeren fosfat camlarından salınan 4 ppm'lik daha düşük bakır konsantrasyonlarının, apoptozun düzenlenmesinde kullanılan HUVEC hücreleri için uygun olduğu belirlenmiştir [37]. Ayrıca, Sen ve Ç.A., 1.6 ppm'den 8 ppm'e kadar, $\mathrm{CuSO}_{4}$ değerlerinin keratinositlerde VEGF’yi (Vasküler Endotelyal Büyüme Faktörü) önemli ölçüde artırdığını bildirmişlerdir [38]. Varmette ve Ç.A. ise, bakır katkılı camların, bakır iyonunun toksik etki gösterdiği 58 ppm'de, herhangi bir terapötik etkisi olmadığını göstermişlerdir [20]. 
Stronsiyum katkılı camların, asellüler biyoaktiviteyi artırdığı, osteoklastların farklılaşmasını azalttığı ve çözünme ortamında stronsiyum iyon salınımının 5-23 ppm aralığında olduğu belirtilmiştir. 8.7- 87.6 ppm aralığındaki stronsiyum iyon konsantrasyonunun, osteoblastlar üzerinde uyarıcı etkilere yol açtığını da açıklamışlardır [9, 21]. Stronsiyum ve bakır salımı çok daha yükssek konsantrasyonlara ulaştığında iyonlar sitotoksik etki göstermekte, hücre bağlanması ve büyümesini olumsuz olarak etkilemekte olduğunu saptamışlardır. Bu nedenle, biyomalzemelerden salınan iyonların kontrol edilmesi önemlidir. Stronsiyum ve bakır iyon salım konsantrasyonlarının, yapı iskelesindeki orijinal iyon miktarı değiştirilerek daha iyi kontrol edilebileceği açıklanmıştır. Bu özellik, periodontal doku mühendisliği için klinik güvenlik gereksinimlerini karşılamak için büyük önem taşımaktadır [39]. Bu sonuçlara göre, stronsiyum katkı1ı BG ve bakır nanoparçacıkları içeren yapı iskelelerinin, bu çalışmada saptanan stronsiyum ve bakır iyonu salım profilleri göz önünde bulundurularak, terapötik potansiyele sahip oldukları söylenebilir.

\section{SONUÇLAR (CONCLUSIONS)}

Bu çalışmada, bakır nanoparçacıklarının varlığında 3D biyoaktif cam-PDLLA kompozit gözenekli yapı iskeleleri, modifiye edilmiş çözücü döküm ve tanecik uzaklaştırma yöntemi kullanılarak üretilmiştir. Yapılan FTIR, XRD ve SEM analiz sonuçları, üretilen tüm yapı iskelesi yüzeylerinde SBF sonrasında HA oluşumunu ortaya koymuştur. Ayrıca, terapötik iyon salınımları sonuçlarına bakıldığında, stronsiyum iyon salınımı 1.27-5.36 ppm aralığında iken, bakır iyon salınımı 1.53-5.42 ppm olarak bulunmuştur. Genel sonuçlar, bu çalışmada üretilen kompozit yapı iskelelerinin kemik dokusu mühendisliği uygulamaları için osteojenik, anjiyojenik ve antibakteriyel potansiyele sahip olabileceğini göstermiştir.

\section{KAYNAKLAR (REFERENCES)}

[1] V.M. Correlo, J.M. Oliveira, J.F. Mano, N.M. Neves, R.L. Reis, Natural origin materials for bone tissue engineering-properties, processing, and performance, Principles of Regenerative Medicine, 2nd ed., (Ch. 32, Part 3), Academic Press, London, 2011.

[2] H.W. Tong, M. Wang, Electrospinning of poly(hydroxybutyrate-co-hydroxyvalerate) fibrous scaffolds for tissue engineering applications: effects of electrospinning parameters and solution properties, Journal of Macromolebakırlar Science Part B, 50: 8 (2011) 1535-1558.

[3] W. Wang, K.W. Yeung, Bone grafts and biomaterials substitutes for bone defect repair: A review. Bioactive Materials. 2 (2017) 224-247.

[4] T. Fiedler, A.C. Videira, P. Bártolo, M. Strauch, G.E. Murch, G.E. J.M.F. Ferreira, On the mechanical properties of PLC-bioactive glass scaffolds fabricated via Bio Extrusion, Material Science and Engineering C, 57 (2015) 288-293.

[5] Y. Ito, H. Hasuda, M. Kamitakahara, C. Ohtsuki, M. Tanihara, I.K. Kang, O.H. Kwon, A composite of hydroxyapatite with electrospun biodegradable nanofibers as a tissue engineering material”, Journal of Bioscience and Bioengineering, 100:1 (2005) 43-49.

[6] Y.H. Kim, Y.K. Min, B.T. Lee, Fabrication and material properties of fibrous PHBV scaffolds depending on the cross-ply angle for tissue engineering, Journal of Biomaterials Applications, 27:4 (2012) 457-468.

[7] Q. Chen, J.A. Roether, A.R. Boccaccini, Tissue engineering scaffolds from bioactive glass and composite materials, Topics in Tissue Engineering, Vol. 4 (Ch. 6), Biomaterials and Tissue Engineering Group, 2008.

[8] A.R. Boccaccini, V. Maquet, Bioresorbable and bioactive polymer Bioglass ${ }^{\circledR}$ composites with tailored pore structure for tissue engineering applications, Composites Science and Technology, 63:16 (2003) $2417-2429$. 
[9] G. Kaur, P. Pandey, K. Singh, D. Homa, B. Scott, G. Pickrell, A review of bioactive glasses: Their structure, properties, fabrication, and apatite formation, Journal of Biomedical Materials Research Part A, 102A (2014) 254-274.

[10] L.L. Hench, R.J. Splinter, W.C. Allen, Bonding mechanisms at the interface of ceramic prosthetic materials, Journal of Biomedical Materials Research Part A, 5:6 (1971) 117-141.

[11] D. Fırat Öztopalan, A.S. Durmuş, Kemik grefti yerine biyoaktif cam kullanımı. Dicle Üniversitesi Veterinerlik Fakültesi Dergisi, 10:1 (2017) 56-61.

[12] K. Rezwan, Q.Z. Chen, J.J. Blaker, A.R. Boccaccini, Biodegradable and bioactive porous polymer/inorganic composite scaffolds for bone tissue engineering. Biomaterials, $27: 18$ (2006) 34133431.

[13] V. Guarino, F. Causa, L. Ambrosio, Bioactive scaffolds for bone and ligament tissue, Expert Review of Medical Devices, 4:3 (2007) 405-418.

[14] E. Zeimaran, S. Pourshahrestani, I. Djordjevic, B. Pingguan-Murphy, N.A. Kadri, M.R. Towler, Bioactive glass reinforced elastomer composites for skeletal regeneration: A review, Material Science of Engineering C, 53 (2015) 175-188.

[15] Q. Yao, W. Li, S. Yu, L. Ma, D. Jin, A.R. Boccaccini, Y. Liu, Multifunctional chitosan/polyvinyl pyrrolidone/45S5 Bioglass ${ }^{\circledR}$ scaffolds for MC3T3-E1 cell stimulation and drug release, Material Science of Engineering C, 56 (2015) 473-480.

[16] Y.W. Chen, G.Q. Shi, Y.L. Ding, X.X. Yu, X.H. Zhang, C.S. Zhao C.S., et al., "In vitro study on the influence of strontium-doped calcium polyphosphate on the angiogenesis-related behaviors of HUVECs", Journal of Material Science: Materials in Medicine, 19 (2008) 2655-2662.

[17] E. Seeman, J.P. Devogelaer, R. Lorenc, T. Spector, K. Brixen, A. Balogh, et al., Strontium ranelate reduces the risk of vertebral fractures in patients with osteopenia. Journal of Bone and Mineral Research, 23 (2008) 433-438.

[18] H. Wang, S. Zhao, J. Zhou, Y. Shen, W. Huang, C. Zhang, et al., Evaluation of borate BG scaffolds as a controlled delivery system for Bakır ions in stimulating osteogenesis and angiogenesis in bone healing, Journal of Materials Chemistry B, 2 (2014) 8547-8557.

[19] M.M. Erol, V. Mouriňo, P. Newby, X. Chatzistavrou, J.A. Roether, L. Hupa, A.R. Boccaccini, Copper-releasing, boron-containing bioactive glass-based scaffolds coated with alginate for bone tissue engineering, Acta Biomaterialia, 8 (2012) 792-801.

[20] S.K. Misra, T.I. Ansari, S.P. Valappil, D. Mohn, S.E. Philip, W.J. Stark, I. Roy, J.C. Knowles, V. Salih, A.R. Boccaccini, Poly(3-hydroxybutyrate) multifunctional composite scaffolds for tissue engineering applications. Biomaterials, 31 (2010) 2806-2815.

[21] M. Erol, A. Özyuğuran, Ö. Özarpat S. Küçükbayrak, 3D Composite scaffolds using Strontium containing bioactive glasses, Journal of European Ceramic Society, 32 (2012) 2747-2755.

[22] T. Kokubo, Z.T. Huang, T. Hayashi, S. Sakka, T. Kitsugi, and T. Yamamuro, "Ca, P-rich layer formed on high-strength bioactive glass-ceramic”, J. Biomed. Mater. Res., 24 (3) 331-343 (1990).

[23] S. Hollister, Porous scaffold design for tissue engineering. Nature Materials, 4 (2005) 518-524.

[24] T. Oliveira, G. Botelho, N.M. Alves, J.F. Mano, Inclusion complexes of $\alpha$-cyclodextrins with poly(D,L -lactic acid): structural, characterization, and glass transition Dynamics. Colloid and Polymer Science, 292 (2014) 863-871. 
[25] R.V. Pereiraa, G.V., Salmoriab, M.O.C. Mouraa, Á. Aragonesc, M.C. Fredela, Scaffolds of PDLLA/Bioglass 58S Produced via Selective Laser Sintering. Materials Research, 17 : 1 (2014) 3338.

[26] A.I. Leal, S.G. Caridade, J. Ma, N. Yu, M.E. Gomes, R.L. Reis, J.A. Jansen, X.F. Walboomers, J.F. Mano, Asymmetric PDLLA membranes containing Bioglass ${ }^{\circledR}$ for guided tissue regeneration: Characterization and in vitro biological behavior. Dental Materials, 29 (2013) 427-436.

[27] C.S. Proikakis, N.J. Mamouzelos, P.A. Tarantili, A.G. Andreopoulos, Stability of DL-poly(lactic acid) in aqueous solutions. Journal of Applied Polymeric Science, 87:5 (2003) 795-804.

[28] M. Catauro, F. Bollino, R.A. Renella, F. Papale, Sol-gel synthesis of $\mathrm{SiO}_{2}-\mathrm{CaO}-\mathrm{P}_{2} \mathrm{O}_{5}$ glasses: Influence of the heat treatment on their bioactivity and biocompatibility. Ceramics International, 41 (2015) 12578-12588.

[29] H. Hajiali, S. Karbasi, M. Hosseinalipour, H.R. Rezaie, Preparation of a novel biodegradable nanocomposite scaffold based on poly (3-ydroxybutyrate)/bioglass nanoparticles for bone tissue engineering. Journal of Material Science: Materials in Medicine, 21 (2010) 2125-2132.

[30] M. Akram, A.Z. Alshemary, Y.F. Goh, W.A.W. Ibrahim, H.O. Lintang, R. Hussain, Continuous microwave flow synthesis of mesoporous hydroxyapatite. Material Science of Engineering C, 56 (2015) 356-362.

[31] A.Z. Alshemary, M. Akram, Y.F. Goh, M.R.A. Kadir, A. Abdolahi, R. Hussain, Structural characterization, optical properties and in vitro bioactivity of mesoporous erbium-doped hydroxyapatite. Journal of Alloys Compounds, 645 (2015) 478-486.

[32] J.L. Ryszkowska, M. Auguścik, A. Sheikh, A.R. Boccaccini, Biodegradable polyurethane composite scaffolds containing Bioglass for bone tissue engineering. Composites Science and Technology, 70 (2010) 1894-1908.

[33] Y. Wan, C. Wu, G. Xiong, G. Zuo, J. Jin, K. Ren, Y. Zhu, Z. Wang, H. Luo, Mechanical properties and cytotoxicity of nanoplate-like hydroxyapatite/polylactide nanocomposites prepared by intercalation technique. Journal of Mechanical Behavior of Biomedical Materials, 47 (2015) 29-37.

[34] A.M. Sofronia, R. Baies, E.M. Anghel, C.A. Marinesbakır, S. Tanasesbakır, Thermal and structural characterization of synthetic and natural nanocrystalline hydroxyapatite. Material Science of Engineering C, 43 (2014) 153-163.

[35] M. Erol, A. Özyuğuran, Ö. Özarpat S. Küçükbayrak, Investigation of Strontium effect on the bioactive behavior glasses in the system $\mathrm{SiO}_{2}-\mathrm{CaO}-\mathrm{P}_{2} \mathrm{O}_{5}-\mathrm{Na}_{2} \mathrm{O}-\mathrm{SrO}$, Key Engineering Materials, 493-494 (2012) 68-73.

[36] C. Gerard, L.J. Bordeleau, J. Barralet, C.J. Doillon, The stimulation of angiogenesis an collagen deposition by copper. Biomaterials, 31 (2010) 824-831.

[37] C. Stähli, N. Muja, S.N. Nazhat, Controlled copper ion release from phosphate-based glasses improves human umbilical vein endothelial cell survival in a reduced nutrient environment. Tissue Engineering Part A, 19 (2013) 548-557.

[38] C.K. Sen, S. Khanna, M. Venojarvi, P. Trikha, E.C. Ellison, T.K. Hunt S. Roy, Copper-induced vasbakırlar endothelial growth factor expression and wound healing. American Journal of Physiology: Heart and Cirbakırlatory Physiology, 282 (2002) H1821-H1827.

[39] C. Wu, Y. Zhou, C. Lin, J. Chang, Y. Xiao, Strontium-containing mesoporous bioactive glass scaffolds with improved osteogenic/cementogenic differentiation of periodontal ligament cells for periodontal tissue engineering. Acta Biomateriala, 8 (2012) 3805-3815. 